\title{
Mortality and survival in rheumatoid arthritis: a 25 year prospective study of 100 patients
}

\author{
P A Reilly, J A Cosh, P J Maddison, J J Rasker, A J Silman
}

\begin{abstract}
One hundred patients with classical (52) or definite (48) rheumatoid arthritis (RA) at one year after onset were followed up for 25 years. By then 63 had died, in one third of whom RA had either directly caused or contributed to death. These patients, at one year after onset of arthritis, had a higher proportion with classical RA and more functional impairment than the rest.

Thirty five of the surviving 37 patients were seen for review. Eleven were well with no functional impairment. At one year after onset they had a lower erythrocyte sedimentation rate (ESR) and higher haemoglobin than the others, in whom a poorer outcome was associated with a persistently raised ESR and lower haemoglobin. The initial Rose-Waaler titre was a poor prognostic guide, but a better functional outcome was associated with conversion to seronegativity or a marked fall in rheumatoid factor level.
\end{abstract}

The wide variations in the course of rheumatoid arthritis (RA) make assessment of prognosis uncertain in the early stages of the disease. Some patients will have a brief period of trouble with no or few sequelae, whereas others with a similar presentation will progress inexorably to severe deformity and disability and may even die of the disease, its complications, or its treatment.

From previous follow up studies of RA there has emerged a consensus that life expectancy is reduced, particularly in those with severe arthritis. ${ }^{1-8}$ To some extent the selection of patients for study influences the results: the outcome is more serious when based on hospital inpatients ${ }^{28}$ and less serious when based on patients with RA identified in population surveys. ${ }^{56}$ Any cross-sectional analysis based on a rheumatology clinic is likely to overrepresent the more serious cases because many patients with milder arthritis will have been discharged from regular review or never referred in the first place. Prospective long term observation of patients from the early stages of their disease offers the most satisfactory way of assessing the course of the disease, its functional outcome, and its effect on mortality, and of retrospectively testing the value of prognostic indicators in the early stages.

We now report on the 25 year review of such a group of 100 patients with RA. Details of earlier reviews of these patients have already been published. $9-12$

\section{Patients and methods}

The 100 patients formed a consecutive series in that all patients referred to JAC with RA of less than a year's duration were accepted into the series if by one year from onset their arthritis met the criteria of the American Rheumatism Association for classical or definite RA. ${ }^{13}$ There were 52 patients with classical RA and 48 with definite RA. The mean age of onset for the 100 was 51 years. There were 64 women (mean age of onset 50 years, range 18-81) and 36 men (mean age of onset 52 years, range 22-73) giving a female:male ratio of $1 \cdot 8: 1$. The mean duration of arthritis when they were first seen was $3 \cdot 7$ months. Previous reviews were made and reported after 11 years, ${ }^{9} 15,{ }^{10} 18,,^{11}$ and 20 years. ${ }^{12}$

In this 25 year follow up review 35 of the 37 surviving patients were seen and the remaining two were contacted by telephone. In each patient seen a history was taken of previous and current drug treatment and orthopaedic surgery, which will be the subject of a separate report. Physical examination included an assessment of joint score and of functional capacity on the following scale: $1=$ fit for all activities; $2=$ moderately restricted; $3=$ severely restricted; $4=$ incapacitated.

Blood was taken for cell count and haemoglobin estimation, erythrocyte sedimentation rate (ESR Westergren), and IgM rheumatoid factor. In earlier reviews rheumatoid factor was assessed by the Rose-Waaler test and in this review by a quantitative nephelometric method (Hyland). There is no simple and reliable way to equate results obtained by these two methods. In an attempt to achieve comparability between them the degree of seropositivity was judged on a four point scale ranging from zero (seronegative) to three (strongly positive) as shown in table 1 .

The pattern of the course of the disease in the 35 patients was defined in the following three categories: (a) remitting: initially active RA for up to five years but with no sustained return of active disease thereafter; $(b)$ chronic relapsing:

Table 1: Comparison of Rose-Waaler titre with IgM rheumatoid factor levels given by nephelometry showing the scoring system for the degree of seropositivity

\begin{tabular}{llll}
\hline $\begin{array}{l}\text { Rose-Waaler } \\
\text { titre }\end{array}$ & $\begin{array}{l}\text { Rheumatoid } \\
\text { factor by } \\
\text { nephelometry } \\
\text { (units/ml) }\end{array}$ & Serostatus & $\begin{array}{l}\text { Serostatus } \\
\text { score }\end{array}$ \\
\hline $1 / 8-1 / 16$ & $\leqslant 40$ & $\begin{array}{l}\text { Seronegative } \\
\text { Weakly positive }\end{array}$ & 0 \\
$1 / 32-1 / 64$ & $41-100$ & $\begin{array}{l}\text { Moderately } \\
\text { seropositive }\end{array}$ & 2 \\
$1 / 128-1 / 256$ & $101-250$ & $\begin{array}{c}\text { Strongly } \\
\text { seropositive }\end{array}$ & 3 \\
$1 / 512-1 / 2048$ & $>250$ & & \\
\hline
\end{tabular}

Royal National Hospital Bath

J A Cosh

Samenwerkende The Netherlands

J Rasker

Epidemiology Researc 
periods of remission lasting 12 months or more but with intermittent return of active disease; (c) chronic persistent: sustained disease activity with no remission lasting as long as 12 months.

The cause of death in the 63 patients who died was ascertained from necropsy reports (in 19), death certificates, and hospital and general practitioner records. As in a previous review ${ }^{11}$ a death was classified as 'attributable' if directly due to RA or its systemic manifestations, 'contributory' if RA or its treatment were considered to have contributed to death without being directly responsible, and 'unrelated' if due to an entirely different cause. For some analyses the attributable and contributory deaths have been summated under the heading of 'RA related'.

Statistical analysis was by $\chi^{2}$, two sample $t$ test, and Mann-Whitney U test where appropriate. Comparison of observed with expected mortality was based on published data from the South West Regional Health Authority after adjusting for age, sex, and year of death. ${ }^{14}$

\section{Results}

MORTALITY

Of the 63 deaths, 21 (seven men, 14 women) were considered to be related to RA, 12 being classed as attributable and nine as contributory. The remaining 42 deaths were considered unrelated to RA.

Attributable deaths (table 2)

Nine attributable deaths were reported in the 18 year review ${ }^{11}$ and another three had occurred by the 25th year. These three were: a man with vasculitis giving rise to a gastric ulcer and a fatal haematemesis and two women with cervical myelopathy due to atlantoaxial subluxation.

\section{Contributory deaths (table 3)}

Seven contributory deaths were reported in the 18 year review, but we have now reclassified one of these as unrelated. He died from reticulosarcoma and had been treated with azathioprine, which was at first thought to have caused this malignancy. He had received the drug for only 10 months, however, and a subsequently published report on the effects of immunosuppressive drugs ${ }^{15}$ suggested that this was too short a period for the drug to have been responsible. Three further deaths were added to this group by the 25th year: a man and a woman both immobilised by severely disabling arthritis and dying in consequence from bronchopneumonia, and a woman with amyloid neuropathy who fell fracturing her pelvis, dying soon afterwards from bronchopneumonia.

All nine deaths in this group were due to forms of terminal infection, with corticosteroids considered to have a role in predisposing to infection in six of the nine.

\section{Unrelated deaths (table 4)}

Forty two unrelated deaths (M 21, F 21) were due to causes unrelated to RA, broadly reflecting the main causes of death in the general population.

Table 2: Twelve deaths attributable to rheumatoid arthritis $(R A)$, showing the basic pathological cause and the mode of death

\begin{tabular}{|c|c|c|c|c|}
\hline $\begin{array}{l}\text { Basic } \\
\text { cause }\end{array}$ & Sex & $\begin{array}{l}\text { Age at } \\
\text { death } \\
\text { (years) }\end{array}$ & $\begin{array}{l}\text { Duration } \\
\text { of } R A \\
\text { (years) }\end{array}$ & Mode of death \\
\hline Vasculitis & $\begin{array}{l}M \\
M \\
M \\
M \\
M\end{array}$ & $\begin{array}{l}62 \\
35 \\
59 \\
49 \\
50\end{array}$ & $\begin{array}{r}3 \\
5 \\
11 \\
14 \\
24\end{array}$ & $\begin{array}{l}\text { Heart block } \\
\text { Malignant hypertension, mesenteric infarct } \\
\text { Gangrene of feet } \\
\text { Septic ulcers, pneumonia } \\
\text { Gastric ulcer, haematemesis }\end{array}$ \\
\hline Amyloid disease & $\begin{array}{l}\mathrm{F} \\
\mathrm{F} \\
\mathrm{M}\end{array}$ & $\begin{array}{l}67 \\
69 \\
74\end{array}$ & $\begin{array}{r}7 \\
9 \\
16\end{array}$ & $\begin{array}{l}\text { Renal failure } \\
\text { Renal failure } \\
\text { Renal failure }\end{array}$ \\
\hline Rheumatoid heart disease & $\mathrm{F}$ & $\begin{array}{l}60 \\
69\end{array}$ & $\begin{array}{l}8 \\
8\end{array}$ & $\begin{array}{l}\text { Constrictive pericarditis, death after operation } \\
\text { Heart block, congestive failure }\end{array}$ \\
\hline Cervical myelopathy & $\begin{array}{l}\mathrm{F} \\
\mathrm{F}\end{array}$ & $\begin{array}{l}53 \\
60\end{array}$ & $\begin{array}{l}25 \\
25\end{array}$ & $\begin{array}{l}\text { Quadriparesis } \\
\text { Quadriparesis }\end{array}$ \\
\hline
\end{tabular}

Mean age at onset of RA: 46 years; mean age at death: 59 years; mean duration of RA: 13 years.

Table 3: Nine deaths to which rheumatoid arthritis $(R A)$ contributed, showing the basic pathological cause and the mode of death

\begin{tabular}{lllll}
\hline $\begin{array}{l}\text { Basic } \\
\text { cause }\end{array}$ & Sex & $\begin{array}{l}\text { Age at } \\
\text { death } \\
\text { (years) }\end{array}$ & $\begin{array}{l}\text { Duration } \\
\text { of } R A \\
\text { (years) }\end{array}$ & Mode of death \\
\hline Immobilised by arthritis & F & 71 & 17 & Renal failure, pyelonephritis, steroids \\
& F & 88 & 19 & Bronchopneumonia, steroids \\
& M & 78 & 22 & Bronchopneumonia \\
Bronchopneumonia, steroids
\end{tabular}

Mean age at onset of RA: 54 years; mean age at death: 70 years; mean duration of RA: 16 years. 
Table 4: Causes of death unrelated to rheumatoid arthritis $(R A)$ in 42 patients (21 male, 21 female)

\begin{tabular}{lcc}
\hline Cause of death & Number \\
\hline $\begin{array}{l}\text { Cardiovascular } \\
\text { Myocardial infarction }\end{array}$ & 14 & \\
$\quad \begin{array}{l}\text { Congestive heart failure } \\
\text { Ruptured aortic aneurysm }\end{array}$ & 2 & \\
Cerebrovascular & 1 & \\
Malignancy & & 12 \\
$\quad$ Bronchus & & 8 \\
$\quad$ Pladder & 3 & \\
$\quad$ Oesophagus & 2 & \\
$\quad$ Reticulosarcoma & 1 & \\
Respiratory & 1 & \\
$\quad$ Bronchopneumonia & 1 & \\
$\quad$ Emphysema & & 4 \\
Renal failure & 2 & \\
Total & 2 & \\
\end{tabular}

Mean age at onset of RA: 59 years; mean age at death: 74 years; mean duration of RA: 15 years.

Observed versus expected deaths

From published data for the population of south west England $^{14}$ the age adjusted expected number of deaths for the 100 over 25 years was 45 (M 19.5, F 25.5) compared with the observed number of 63 deaths (M 28, F 35). The excess mortality:

$$
\frac{\text { Observed deaths }- \text { expected deaths }}{\text { Expected deaths }} \times 100
$$

for the 100 patients was $40 \%$. The figure for men was $44 \%$ and for women $37 \%$. The difference between these two figures is not significant, indicating that although the death rate among men patients was greater than among women, this did not differ significantly from the greater male mortality expected in the general population.

Table 5 shows a comparison between observed

Table 5: The observed 63 deaths in the 100 patients, listed under major causes and compared with the expected 45 deaths in a matched population over 25 years

\begin{tabular}{|c|c|c|c|c|}
\hline \multirow[t]{2}{*}{$\begin{array}{l}\text { Causes of } \\
\text { death }\end{array}$} & \multicolumn{2}{|c|}{$\begin{array}{l}\text { Observed deaths } \\
(n=63)\end{array}$} & \multicolumn{2}{|c|}{$\begin{array}{l}\text { Expected deaths } \\
(n=45)\end{array}$} \\
\hline & Number & $\%$ & Number & $\%$ \\
\hline $\begin{array}{l}\text { RA attributable } \\
\text { Cardiovascular } \\
\text { Cerebrovascular } \\
\text { Respiratory* } \\
\text { Malignancy } \\
\text { Other }\end{array}$ & $\begin{array}{r}12 \\
17 \\
12 \\
8 \\
8 \\
6\end{array}$ & $\begin{array}{r}19 \\
27 \\
19 \\
13 \\
13 \\
9\end{array}$ & $\begin{array}{r}\overline{12} \\
6 \\
6 \\
11 \\
10\end{array}$ & $\begin{array}{l}\overline{27} \\
13 \\
13 \\
24 \\
22\end{array}$ \\
\hline
\end{tabular}

${ }^{*}$ Respiratory deaths include bronchopneumonia. and expected mortality from the major causes of death. The figures suggest that in our patients deaths from cerebrovascular causes were more common than expected, with the reverse true for deaths from malignancy. The small numbers limit the reliability of any conclusions, however.

\section{Prognostic indicators}

Data from the first year of arthritis were reviewed for possible prognostic indicators which might at that time have identified the 21 patients who ultimately died of RA related causes.

After one year of arthritis there was no significant difference between the 35 survivors and the $\mathbf{4 2}$ who died of causes unrelated to RA as regards severity of arthritis (classical $v$ definite RA), degree of seropositivity, functional capacity, mean ESR, haemoglobin, and joint score. The two groups differed only in age, the survivors having developed arthritis at a mean age of 41 years and the deceased patients at 59 years. It was therefore considered justifiable to combine the two to make a single group of 77 patients for comparison with the 21 (table 6).

This shows that only two features distinguished the 21 who later died of RA related causes: they already had a poorer functional capacity and significantly more had classical rather than definite RA. There were no significant differences in the numbers with strong seropositivity, in mean ESR, haemoglobin, or joint score. A further analysis showed no relation between the joint score or rheumatoid factor level at one year and the survival rate adjusted for age and sex.

\section{SURVIVORS}

Of the 37 patients surviving after 25 years, eight were men, of average age 67 years (range 47-82) and 29 were women, also of average age 67 years (range 42-85). The sex ratio (F:M) had thus become $3 \cdot 6: 1$ compared with the original $1 \cdot 8: 1$ as a result of the higher mortality in men patients. Thirty five of the 37 attended hospital for review. The remaining two women were contacted by telephone; one of them was in complete remission and the other reported only occasional pain and swelling in one knee.

Functional capacity

Table 7 shows that 26 of the 35 patients were in

Table 6: Comparison at one year between the 2.I patients who later died of rheumatoid arthritis (RA) related causes and the remaining 77 patients

\begin{tabular}{|c|c|c|c|}
\hline & $\begin{array}{l}\text { Deaths } \\
\text { related to } R A \\
(n=21)\end{array}$ & $\begin{array}{l}35 \text { Survivors } \\
+42 \text { deaths } \\
\text { unrelated to } R A \\
(n=77)\end{array}$ & p Value \\
\hline $\begin{array}{l}\text { Age at onset in years (SD) } \\
\text { RA classical } \\
\text { RA definite } \\
\text { Strongly seropositive (RF* score } 3 \text { ) } \\
\text { Functional class } 1 \\
\text { Mean ESR mm/h (SD) } \\
\text { Mean haemoglobin (g/l) (SD) } \\
\text { Mean joint score (SD) }\end{array}$ & $\begin{array}{l}50(13) \\
16(76 \%) \\
5(24 \%) \\
10(48 \%) \\
6(28 \%) \\
55(29) \\
111(15) \\
5 \cdot 6(2 \cdot 3)\end{array}$ & $\begin{array}{l}51(11) \\
37(48 \%) \\
40(52 \%) \\
44(57 \%) \\
50(65 \%) \\
47(30) \\
117(17) \\
4 \cdot 7(2.6)\end{array}$ & $\begin{array}{l}\text { NS } \\
<0 \cdot 001 \\
\text { NS } \\
<0 \cdot 01 \\
\text { NS } \\
\text { NS } \\
\text { NS }\end{array}$ \\
\hline
\end{tabular}

${ }^{*} \mathrm{ESR}=$ erythrocyte sedimentation rate; $\mathrm{RF}=$ rheumatoid factor. 
Table 7: Functional capacity of the 35 surviving patients, with the corresponding clinical data for each of the four classes

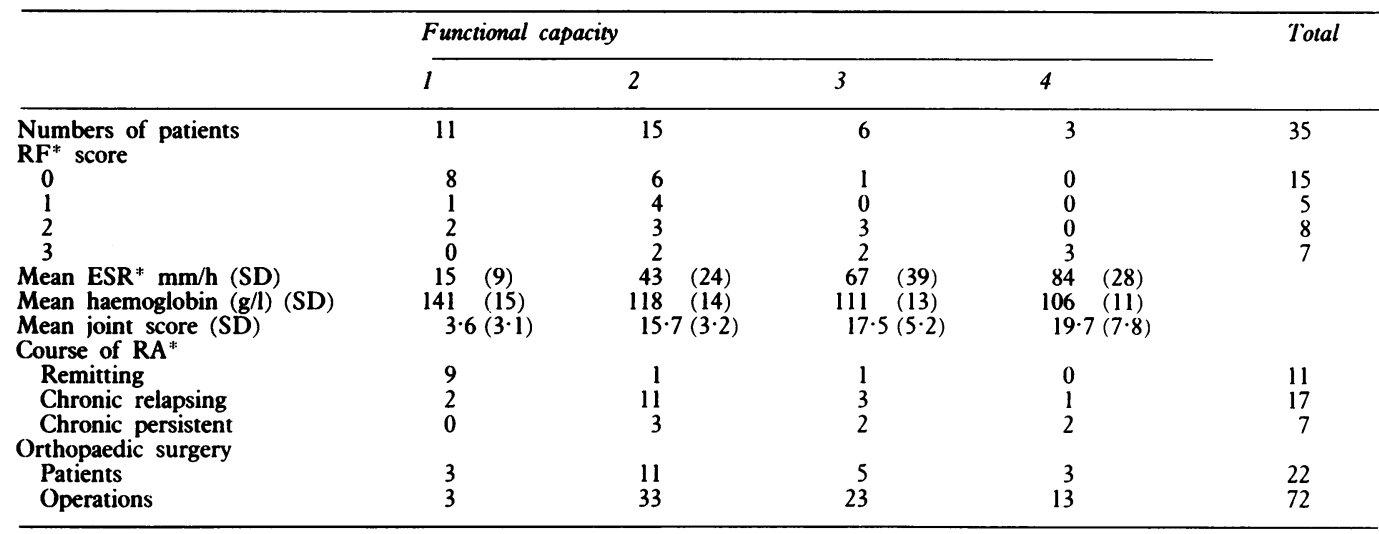

The 11 patients in class 1 were better than the rest in all respects and had the least need for orthopaedic surgery. ${ }^{\text {*}} \mathrm{ESR}=$ erythrocyte sedimentation rate; $\mathrm{RA}=$ rheumatoid arthritis; $\mathrm{RF}=$ rheumatoid factor.

classes 1 or 2 of functional capacity, as were 14 of the 15 patients now seronegative (rheumatoid factor score 0 ). The 11 patients in functional class 1 were clearly better than the remainder as regards mean ESR, haemoglobin, and joint score.

A review of the changes in functional capacity of the 35 patients over the course of 25 years showed that 27 were in class 1 after one year, this figure falling to 16 at the 11 year survey, 12 at 18 years, and 11 now.

\section{Course pattern of arthritis}

The arthritis had a remitting pattern in 11 of the $35(31 \%)$, nine of whom were now in functional class 1 . The course was designated chronic in the remaining $24,17(49 \%)$ having a relapsing pattern and seven (20\%) persistently active arthritis.

Orthopaedic surgery

Only three of the 11 patients now in functional class 1 needed surgery during the 25 years: two had knee synovectomies and the third had carpal tunnel decompressions. Eleven of the 15 in functional class 2 needed surgery, having 33 operations in all, some being of a major nature: four had bilateral hip replacements, one a knee replacement, and one needed surgical stabilisation of cervical spine. Five of the six in functional class 3 had surgery, four having hip replacements (in two patients bilateral) and there were seven knee replacements. The three patients in functional class 4 had all needed major joint surgery, one having cervical stabilisation and the other two having bilateral hip replacements among other operations.

Patients with greater impairment of function thus had a greater need for surgery during the course of their arthritis. There can be no doubt that the functional capacity of some of those now in classes 2 and 3 would have been worse without surgery.

\section{Prognostic indicators}

Data from the first year of arthritis were reviewed for indicators which might at that stage distinguish the 11 patients now in functional class 1 from the 24 in classes 2,3 , and 4 (table 8).

At one year a favourable feature in the 11 was a higher proportion then in functional class 1 , also more were seronegative, but the numbers were small. The 11 had a significantly lower mean ESR than the rest at one year but did not differ from them in haemoglobin or joint score.

There was no single valid indicator of prog-

Table 8: Clinical data on the 35 surviving patients showing past and present differences between the 11 now in functional class 1 and the remaining 24

\begin{tabular}{|c|c|c|c|}
\hline & $\begin{array}{l}\text { Functional } \\
\text { capacity } 1 \\
(n=I I)\end{array}$ & $\begin{array}{l}\text { Functional } \\
\text { capacity } 2,3 \text {, and } 4 \\
(\boldsymbol{n}=24)\end{array}$ & $\stackrel{p}{\text { Value }}$ \\
\hline $\begin{array}{l}\text { Functional capacity } 1 \\
\text { At I year }\end{array}$ & $10(91 \%)$ & $17(71 \%)$ & \\
\hline $\begin{array}{l}\text { Rheumatoid factor } \\
\text { At } 1 \text { year, score } 3 \\
\text { At } 1 \text { year score } 0 \\
\text { At } 25 \text { years score } 3 \\
\text { At } 25 \text { years score } 0\end{array}$ & $\begin{array}{l}8(73 \%) \\
3(27 \%) \\
0 \\
8(73 \%)\end{array}$ & $\begin{array}{c}20(83 \%) \\
1(4 \%) \\
7(29 \%) \\
7(29 \%)\end{array}$ & \\
\hline $\begin{array}{l}\text { Mean } \mathrm{ESR}^{*} \mathrm{~mm} / \mathrm{h}(\mathrm{SD}) \\
\text { At } 1 \text { year } \\
\text { At } 25 \text { years }\end{array}$ & $\left.\begin{array}{l}33(17 \cdot 6) \\
15(9 \cdot 1)\end{array}\right\} t$ & $\begin{array}{l}52(31 \cdot 5) \\
54(31 \cdot 1)\end{array}$ & $\begin{array}{l}<0.05 \\
<0.001\end{array}$ \\
\hline $\begin{array}{l}\text { Mean haemoglobin } \mathrm{g} / \mathrm{l}(\mathrm{SD}) \\
\text { At } 1 \text { year } \\
\text { At } 25 \text { years }\end{array}$ & $\begin{array}{l}123(18) \\
141(15)\end{array} \mid \ddagger$ & $\begin{array}{l}114(13) \\
115(14)\end{array}$ & $\begin{array}{l}\text { NS } \\
<0.001\end{array}$ \\
\hline $\begin{array}{l}\text { Mean joint score }(\mathrm{SD}) \\
\text { At } 1 \text { year } \\
\text { At } 25 \text { years }\end{array}$ & $\begin{array}{l}3.7(2 \cdot 6) \\
3.6(3 \cdot 1)\end{array}$ & $\begin{array}{r}4 \cdot 8(2 \cdot 2) \\
16.6(4 \cdot 4)\end{array}$ & $\begin{array}{l}\text { NS } \\
<0.001\end{array}$ \\
\hline
\end{tabular}

${ }^{*} \mathrm{ESR}=$ erythrocyte sedimentation rate.

tp<0.01

$\neq \mathrm{p}<0.05$. 
nosis identifiable at one year, but a combination of features indicating patients with milder arthritis was seen to have a bearing on prognosis. There were 12 patients who at one year were in functional class 1 with an ESR under $50 \mathrm{~mm} / \mathrm{h}$, haemoglobin over $110 \mathrm{~g} / \mathrm{l}$, and a joint score of 4 or less. Of these 12 patients, seven remained in functional class 1 after 25 years and seven converted from strongly seropositive to seronegative; of the other 23 patients without these criteria only four remained in functional class 1 and only three converted to seronegative $(\mathbf{p}<0.001)$.

\section{Progress}

Changes seen between the first and the 25th year clearly favoured the 11, illustrating their mainly remitting course (table 8). None of them remained strongly seropositive after 25 years and five had converted to negative. Significant improvement was seen in the mean ESR and haemoglobin of the 11 and their mean joint score remained unchanged while it markedly increased in the other 24 patients.

Some degree of fall in the level of rheumatoid factor occurred in $\mathbf{2 4}$ of the $\mathbf{3 5}$ patients and such falls were greater in those patients with a better functional outcome. There were 15 instances of a major fall in rheumatoid factor by a score of 2 or 3: 14 of these 15 were in patients who were finally in functional classes 1 and 2; there was only one major fall in those patients finally in functional classes 3 and 4 .

\section{Discussion}

The potentially life threatening nature of RA has been noted in a number of previous reports, but comparison between them is difficult because of the different methods and statistics used. For example, studies may be prospective $^{7}$ or retrospective, ${ }^{4}$ they may be based on hospital inpatients ${ }^{12}$ or outpatients, ${ }^{9}$ they may rely on death certificates ${ }^{16}$ or necropsy data, ${ }^{17}$ death certificates being less reliable in establishing the contribution of RA to death. Early studies might have included some patients with arthropathies resembling $\mathrm{RA}$, such as psoriatic arthritis, Reiter's disease, and viral infections, though this error is less likely today.

Our own patients were in some respects selected. In the first place, all were initially serious enough to have been referred to a specialist clinic and, secondly, our series was composed only of those with classical or definite RA. The exclusion of probable and possible RA made for greater diagnostic accuracy but might have excluded a number of milder cases.

Statistical methods also vary in different studies. Earlier reports simply expressed each cause of death as a percentage of all deaths. In more recent studies standardised mortality ratios are given, comparing the observed numbers of deaths with those expected in a control population matched for age and sex. Each cause of death can then be given a relative risk, a figure greater than unity indicating a higher than expected risk, a figure lower than unity indicating a lower than expected risk.

Whatever the investigative methods, various studies concur in showing that RA may be the cause of death, or at least may reduce life expectancy. ${ }^{18}$ Cobb et al concluded that life expectancy was reduced particularly in men whose arthritis began under 50 years of age, ${ }^{1}$ though Duthie et al and Uddin et al found an increased mortality in both sexes and at all ages of onset. ${ }^{2} 3$ Prior et al found a threefold increase in mortality, ${ }^{19}$ while Allebeck found mortality increased 2.5 times on average, with the greatest increase among young and middle aged women." Vandenbroucke et al in a 25 year prospective follow up study showed that median life expectancy was reduced by seven years in men with RA but only by three years in women. ${ }^{7}$ Mitchell et al in a 12 year study of 805 patients found mortality increased by $50 \%$ in comparison with the general population. ${ }^{20}$ Our own study found that RA caused an excess mortality of some $40 \%$ over a 25 year period in both men and women.

We found that 12 of the 63 deaths (19\%) were directly attributable to RA, and in a further nine $(14 \%)$ RA was a contributory factor. Thus one third of deaths were related to RA, its complications, or its treatment. This figure is slightly lower than in some previous reports. Constable et al found $44 \%$ of deaths to be related to $\mathrm{RA},{ }^{21}$ Allebeck found $38 \%,{ }^{6}$ and Benn and Wood $50 \% .^{22}$ Our lower figure may be due to our longer follow up period increasing the likelihood of mortality from other causes in an aging population.

Table 9 shows the main causes of death in seven published series of patients with RA followed up for periods of nine years or more,

Table 9: Causes of death (given as percentages) in this and seven previous studies of mortality in rheumatoid arthritis (RA):

\begin{tabular}{|c|c|c|c|c|c|c|c|c|}
\hline $\begin{array}{l}\text { Author } \\
\text { Year } \\
\text { Reference } \\
\text { Patients (n) } \\
\text { Follow up (years) } \\
\text { Deaths (n) }\end{array}$ & $\begin{array}{c}\text { Cobb } \\
1953 \\
1 \\
583 \\
9 \cdot 6 \\
137\end{array}$ & $\begin{array}{l}\text { Duthie } \\
1964 \\
2 \\
307 \\
9 \\
75\end{array}$ & $\begin{array}{l}\text { Uddin } \\
1970 \\
3 \\
475 \\
10 \\
94\end{array}$ & $\begin{array}{l}\text { Prior } \\
1984 \\
19 \\
489 \\
11 \cdot 2 \\
199\end{array}$ & $\begin{array}{c}\text { Vandenbroucke } \\
1984 \\
7 \\
209 \\
25 \\
165\end{array}$ & $\begin{array}{l}\text { Mutru } \\
1985 \\
5 \\
1000 \\
10 \\
352\end{array}$ & $\begin{array}{l}\text { Scot1 } \\
1987 \\
23 \\
112 \\
20 \\
37\end{array}$ & $\begin{array}{l}\text { Reilly } \\
1989 \\
\text { This study } \\
100 \\
25 \\
63\end{array}$ \\
\hline $\begin{array}{l}\text { Causes of death } \\
\text { Cardiovascular and cerebrovascular } \\
\text { Infection: all sites } \\
\text { Infection (respiratory) } \\
\text { Malignancy } \\
\text { Renal and genitourinary }\end{array}$ & $\begin{array}{c}37 \\
25 \\
(12) \\
11\end{array}$ & $\begin{array}{r}46 \\
15 \\
-13\end{array}$ & $\begin{array}{c}51 \\
19 \\
(14) \\
8\end{array}$ & $\begin{array}{c}39 \\
16 \\
(14) \\
15\end{array}$ & $\begin{array}{c}43 \\
14 \\
\text { (11) } \\
20\end{array}$ & $\begin{array}{l}47 \\
10 \\
(8) \\
12\end{array}$ & $\begin{array}{c}35 \\
27 \\
(16) \\
16\end{array}$ & $\begin{array}{c}46 \\
17 \\
(10) \\
13\end{array}$ \\
\hline $\begin{array}{l}\text { excluding amyloid if known } \\
\text { Gastrointestinal } \\
\text { Rheumatoid disease including }\end{array}$ & $\begin{array}{r}10 \\
6\end{array}$ & $\begin{array}{r}17 \\
8\end{array}$ & $\begin{array}{l}2 \\
2\end{array}$ & $\begin{array}{l}3 \\
6\end{array}$ & $\begin{array}{l}6 \\
3\end{array}$ & $-^{12}$ & $-^{8}$ & $-^{2}$ \\
\hline $\begin{array}{l}\text { amyloid and vasculitis } \\
\text { Other }\end{array}$ & $\begin{array}{l}3 \\
8\end{array}$ & -1 & $\begin{array}{r}2 \\
16\end{array}$ & $\begin{array}{r}17 \\
4\end{array}$ & $\begin{array}{r}10 \\
4\end{array}$ & $\begin{array}{r}8 \\
11\end{array}$ & $\overline{14}$ & $\begin{array}{r}19 \\
3\end{array}$ \\
\hline
\end{tabular}

${ }^{*}$ Some of the figures-for example, those for renal disease, amyloid, and infection, are not strictly comparable (see text for details). 
compared with our own figures. For the reasons already given, comparison between different series of patients has its limitations. Furthermore, different authors have not always classified the causes of death in the same way. Thus deaths due to bronchopneumonia are shown in some cases under 'respiratory' and in others under 'infection'; death from renal failure due to amyloid might be classified under 'genitourinary and renal' or under 'rheumatoid arthritis and its complications'. Not all authors identify RA or 'rheumatoid disease' as a cause of death.

Cardiovascular events were responsible for $27 \%$ of the deaths in our patients, and cerebrovascular disease for another $19 \%$, making a total of $46 \%$ due to vascular disease as distinct from vasculitis. This is similar to the findings in other series quoted in table 9. The extensive study of Mutru et al found a sex difference for deaths from vascular disease in RA, which accounted for $55 \%$ of deaths in men and $35 \%$ in women. ${ }^{5}$ In an earlier necropsy study of rheumatoid patients Mutru et al found $32 \%$ of deaths due to vascular disease compared with $42 \%$ in controls. ${ }^{17}$ Similarly, Vandenbroucke et al found a slightly lower figure for vascular disease as compared with controls, with a mortality ratio of $0 \cdot 9 .{ }^{7}$ Mitchell et al found a mortality of $43 \%$ in rheumatoid patients compared with $48 \%$ in a control population. ${ }^{20}$ Our own figures are very close to these-namely, $46 \%$ in patients compared with $43 \%$ in controls. It appears therefore that the prevalence of fatal vascular disease in rheumatoid patients is little different from that in the general population.

Infection is a common terminal event in RA, estimates of its prevalence ranging between $10 \%{ }^{5}$ and $27 \% .^{23}$ Chronic illness, immobilisation, and the use of corticosteroids and immunosuppressive drugs all reduce resistance to infection. Scott et al regarded corticosteroid treatment as a contributory factor in $27 \%$ of deaths in their series. ${ }^{23}$ Baum, however, pointed out that infection was a common cause of death in RA before these agents came into use, ${ }^{24}$ and Walker noted a higher prevalence of bronchitis in patients with RA even before the onset of arthritis. ${ }^{25}$ In our series 10 patients (16\%) died as a result of infection, six of them having bronchopneumonia.

Malignant disease was responsible for $13 \%$ of the deaths in our patients, a figure lower than in a control population, and comparable with others cited in table 9 , where the range is from 8 to $20 \%$. One of our patients died from reticulosarcoma, which we saw as one of the risks associated with RA rather than the result of the short period of his treatment with azathioprine.

Malignant disease in general seems to have a reduced prevalence in $\mathrm{RA}$, but there is good evidence that neoplasia in the lymphoreticular system is increased, as originally suggested by Lea. ${ }^{26}$ Although not at first confirmed, ${ }^{27}{ }^{28}$ the large scale review by Isomaki et al convincingly showed a greater risk in both men and women with RA for Hodgkin's and non-Hodgkin's lymphoma, leukaemia, and myeloma. ${ }^{29}$ Furthermore, Prior $e t$ al showed that in patients with RA the risk of death from tumours of the reticuloendothelial system was increased by eight times and from lymphoma in particular by 23 times. ${ }^{30}$ Kinlen's study on the long term effects of cytotoxic agents showed an increase in lymphoma by 13 times in patients with RA treated with azathioprine or cyclophosphamide, the latter also causing a threefold increase in bladder cancer. ${ }^{15}$

Renal disease in the form of papillary necrosis is no longer a problem in the treatment of RA since the withdrawal of phenacetin, but chronic renal failure due to amyloid is a potential cause of death. Four of our patients who died had amyloid $(6 \%)$ and three of them died in renal failure. In Cobb's series $13 \%$ died of renal disease, $3 \%$ being due to amyloid. ${ }^{\prime}$ Renal disease accounted for $17 \%$ of deaths in Duthie's report, ${ }^{2}$ but the number due to amyloid was not specified. Mutru et al reported $12 \%$ of deaths from renal disease with amyloid contributing a further $8 \% \%^{5}$; in Uddin's report amyloid caused $2 \%$ of deaths. ${ }^{3}$ In the necropsy study of Mutru et al $27 \%$ of patients had evidence of chronic renal disease compared with only $3 \%$ in the controls, and amyloid was found in $17 \%$ of the rheumatoid group. ${ }^{17}$ The precise figure for the presence of amyloid depends on how thoroughly the evidence for it is sought.

Rheumatoid vasculitis was the underlying pathological cause in five of our 12 patients whose deaths were attributable to RA; all five were men. The morbidity and high mortality associated with vasculitis and extra-articular disease has been found by many previous authors. Recently, Ehrhardt et al noted a particularly high male mortality in this group. ${ }^{8}$ Two other deaths specifically attributed to RA in our patients were caused by spinal cord compression due to cervical subluxation. This mode of death, seldom noted in other reviews, is associated with longstanding RA; the duration of arthritis in both of our patients was 25 years. In the 12 year follow up series of Mitchell et al there were two such deaths among a total of 251.20

The 37 surviving patients were predominantly female (sex ratio $3 \cdot 6: 1$ ) and were on average 16 years younger at the onset of RA than those who died (aged 40 years compared with 56). In making a prognosis in the early stages of RA two points in favour of lengthy survival would obviously therefore be youth and female sex. Our observations also indicate that a better long term prognosis is associated with milder disease at one year after onset, as seen in those patients then in functional class 1 with an ESR under 50 $\mathrm{mm} / \mathrm{h}$, haemoglobin over $110 \mathrm{~g} / \mathrm{l}$, and a joint score of 4 or less.

Conversely, we noted two features early in the course of RA associated with a serious prognosis: these were classical rather than definite RA at one year after onset with impaired functional capacity. At the 25 year follow up we noted that reduced functional capacity was associated with a relatively low haemoglobin (mean $115 \mathrm{~g} / \mathrm{l}$ ) and a raised ESR (mean 54 $\mathrm{mm} / \mathrm{h}$ ). Both haemoglobin and the ESR may be considered as markers of inflammation, control of which will reduce the progression in joint damage. ${ }^{31}$ For patients with chronic RA it is the extent of erosive joint disease which largely 
determines functional capacity, hence the importance of seeking to suppress inflammation therapeutically. Rheumatoid factor is also related to outcome, ${ }^{32}$ but we found the initial level to be a poor prognostic guide, though marked falls in rheumatoid factor correlated well with preservation of function.

With the perspective of our 25 year follow up it was possible to make a simple classification of the pattern of the course taken by the arthritis in individual patients. Not surprisingly the remitting pattern seen in 11 of the survivors was associated with a good functional outcome. It was in these patients that we saw a falling ESR, rising haemoglobin, a static joint score, and the greatest fall in rheumatoid factor levels, generally with conversion to seronegativity. A pattern of chronically active arthritis, particularly of the persistent rather than the remitting and relapsing pattern, has the worst result in terms of joint damage and reduced functional capacity. We cannot claim that the remitting pattern was necessarily the result of treatment, but see it essentially as a spontaneous dying down of the disease process in some patients, marked by an improvement in the indices of inflammation, of joint damage, and a fall in rheumatoid factor.

Many patients with rheumatoid arthritis are never seen by a rheumatologist, ${ }^{34}$ but when they are, the hope is often expressed that the disease will eventually burn out. This appears to have been the case in about one third of our surviving patients, but the other two thirds continue to have active arthritis requiring regular supervision and treatment, sometimes surgical. According to Buchanan ${ }^{35}$ and Silman, ${ }^{36}{ }^{37}$ however, there are grounds for optimism. Perhaps RA is becoming not only less common but also less severe and we will see less severe joint damage, less vasculitis, amyloid, and extra-articular complications in the future. Aggressive use of cytotoxic drugs and combination chemotherapy may diminish both morbidity and mortality in RA. Long term prospective studies will be necessary to confirm such optimism. From our own study, however, we must conclude that rheumatoid arthritis remains a serious disease for many patients, one in five of whom are likely to die as a result of their disease. We are grateful to Dr Nick Golding for statistical advice and to
Mrs Jean Wright and Mrs Hazel Wills for secretarial assistance, and to Miss K Davies, BSc, for computer analysis of data.

1 Cobb S, Anderson F, Bauer W. Length of life and cause of death in rheumatoid arthritis. $N$ Engl f Med 1953; 249: $553-6$.

2 Duthie J J R, Brown P E, Truelove L H, Baragar F D, Lawrie A J. Course and prognosis in rheumatoid arthritis: a further report. Ann Rheum Dis 1964; 23: 193-204.

3 Uddin J, Kraus A S, Kelly H G. Survivorship and death in rheumatoid arthritis. Arthritis Rheum 1970; 13: 125-30.

4 Monson R R, Hall A P. Mortality among arthritics. $f$ Chronic Dis 1976; 29: 459-67.

5 Mutru O, Laakso M, Isomaki H A, Koota K. Ten year mortality and causes of death in patients with rheumatoid arthritis. Br Med F 1985; 290: 1797-9.

6 Allebeck P. Increased mortality in rheumatoid arthritis. Scand 7 Rheumatol 1982; 11: 81-6.

7 Vandenbroucke J P, Hazevoet H M, Cats A. Survival and cause of death in rheumatoid arthritis: a 25 year prospective follow-up. I Rheumatol 1984; 11: 158-61.

8 Ehrhardt C C, Mumford P A, Venables P R W, Maini R N. Factors predicting a poor life prognosis in rheumatoid arthritis: an eight year prospective study. Ann Rheum Dis 1989; 48: 7-13.

9 Jacoby R K, Jayson M I V, Cosh J A. Onset, early stages and prognosis of rheumatoid arthritis. A clinical study of 100 patients with 11 year follow-up. Br Med f 1973; i: 96-100.

10 Rasker J J, Cosh J A. The natural history of rheumatoid arthritis: a 15 year follow-up study. The prognostic significance of features noted in the first year. Clin Rheumatol 1984; 3: 11-20.

11 Rasker J J, Cosh J A. Cause and age at death in a prospective study of 100 patients with rheumatoid arthritis. Ann Rheum study of 100 patients with
Dis 1981; 40: 115-20.

12 Cosh J A, Rasker J J. A 20 year follow-up study of 100 patients with rheumatoid arthritis. Ann Rheum Dis 1982; 41: 317.

13 Ropes M W, Bennett G A, Cobb A, Jacox R F, Jessar R A. Revision of diagnostic criteria for rheumatoid arthritis. Bull Rheum Dis 1958; 9: 175-6.

14 Office of Populations, Censuses and Surveys. Mortality statistics, England and Wales. Series DH5. London: HMSO, $1974-87$.

15. Kinlen L J. Incidence of cancer in rheumatoid arthritis and other disorders after immunosuppressive therapy. Am $\mathcal{F}$ Med 1985; 78: 44-9.

16 Laakso M, Isomaki H A, Mutru O, Koota K. Death certificate and mortality in rheumatoid arthritis. Scand $\mathcal{f}$ Rheumatol 1986; 15: 129-33.

17 Mutru O, Koota K, Isomaki H A. Causes of death in autopsied rheumatoid arthritis patients. Scand $\mathcal{f}$ Rheumatol 1976; 5: 239-40.

18 Cosh J A. Survival and death in rheumatoid arthritis. 7 Rheumatol 1984; 11: 117-9.

19 Prior P, Symmons D P M, Scott D L, Brown R, Hawkins C F. Cause of death in rheumatoid arthritis. $\mathrm{Br} \mathcal{F}$ Rheumatol 1984; 23: 92-9.

20 Mitchell D M, Spitz P W, Young D Y, Bloch D A, McShane D J, Fries J F. Survival, prognosis and causes of death in rheumatoid arthritis. Arthritis Rheum 1986; 29: 706-14.

21 Constable T J, McConkey B, Paton A. The cause of death in rheumatoid arthritis. Ann Rheum Dis 1978; 37: 569.

22 Benn R T, Wood P H. Mortality in rheumatoid arthritis. British foumal of Preventive Medicine 1972; 26: 60.

23 Scott D L, Symmons D P M, Coulton P L, Popert A J. Long term outcome of treating rheumatoid arthritis: results after 20 years. Lancet 1987; i: $1108-11$.

24 Baum J. Infection in rheumatoid arthritis. Arthritis Rheum 1971; 14: 135-7.

25 Walker W C. Pulmonary infections in rheumatoid arthritis. Qf Med 1967; 67: 239.

26 Lea A J. An association between the rheumatic diseases and the reticuloses. Ann Rheum Dis 1964; 23: 480-4.

27 Miller D G. The association of immune disease and malignant lymphoma. Ann Intern Med 1967; 66: 507-21.

28 Owen D T, Waller M, Toone E. Rheumatoid arthritis and malignancy. Arthritis Rheum 1967; 10: 302-3.

29 Isomaki H A, Hakulinen T, Joutsenlahti U. Excess risk of lvmphomas, leukaemia and myeloma in patients with rheumatoid arthritis. I Chronic Dis 1978; 31: 691-6.

30 Prior P, Symmons D P M, Hawkins C F, Scott D L, Brown R. Cancer morbidity in rheumatoid arthritis. Ann Rheum Dis 1984; 43: 128-31.

31 Dawes P T, Fowler P D, Clarke S, Fisher J, Lawton A, Shadforth M F. Rheumatoid arthritis: treatment which controls the C-reactive protein and erythrocyte sedimentation
rate reduces radiological progression. Br f Rheumatol 1986; rate reduces

32 Cats A, Hazevoet H M. Significance of positive tests for rheumatoid factor in the prognosis of rheumatoid arthritis. Ann Rheum Dis 1970; 29: 254-9.

33 Feigenbaum S L, Masi A T, Kaplan S B. Prognosis in rheumatoid arthritis - a longitudinal study of newly diagnosed younger patients. Am F Med 1979; 66: 377-84.

34 Kellgren J H, Lawrence J S, Aitken-Swan J. Rheumatic complaints in an urban population. Ann Rheum Dis 1953; 12: $5-15$.

35 Buchanan W W, Murdoch R M. Hypothesis: that rheumatoid arthritis will disappear. 7 Rheumatol 1979; 6: 324-9.

36 Silman A J, Davies P, Currey H L F, Evans S J. Is rheumatoid arthritis becoming less severe? f Chronic Dis 1983; 36: 891-7.

37 Silman A J. Recent trends in rheumatoid arthritis. $\mathrm{Br} . \mathrm{F}$ Rheumatol 1986; 25: 328-30. 